\title{
Anatomical features, fatty acid profile and tocopherol content of the Tunisian Cakile maritima subsp. maritima Scop. Fruit
}

\author{
Sondes Stambouli-Essassi*1, Faiza Mejii ${ }^{2}$, Manel Dhoueibi ${ }^{1}$, Yassine Mrabet $^{2}$, Fethia \\ Harzallah-Skhiri ${ }^{3}$, Karim Hosni ${ }^{2}$ \\ ${ }^{1}$ Laboratory of Bioresources, Biotechnology and Climate Change, Faculty of Sciences of Tunis, University of Tunis El Manar, \\ Manar II, 1060 Tunis, Tunisia \\ ${ }^{2}$ Laboratory of Natural Substances, National Institute for Research and Physicochemical Analysis, Technological Center of Sidi \\ Thabet, 2020 Tunis, Tunisia \\ ${ }^{3}$ Laboratory of Bioresources: Integrative Biology and V alorization (LR14-ESO6), High Institute of Biotechnology of Monastir, \\ University of Monastir, Tahar Haddad Street, 5000 Monastir, Tunisia \\ Corresponding author, e-mail: sondesessassi@,topnet.tn; Phone: 0021622572106
}

Key words: Cakile maritima subsp. maritima Scop., anatomical features, fatty acid, tocopherol

Publication date 31/01/2020, http://m.elewa.org/Journals/about-japs/

$1 \quad$ ABSTRACT

This study reported for the first time anatomical features, fatty acid composition and tocopherol content for the fruits of Cakile maritima subsp. maritima Scop. collected from two sites located at the coastal part of North Tunisia (Bizerte and Soliman). Anatomical investigations characterized the indehiscent siliqua of Soliman population. Transverse sections through fresh fruit show a large number of prismatic crystals located at the three first layers of the mesocarp, which parenchyma was characterized by the presence of large amounts of starch grains and solitary oil drops. A particular anatomical structure is identified at the valves junction. The endocarp is a thin tissue composed of 2-3 layers of small lignified wall cells and one layer of tangentially elongated and thin cells surrounding the seed. Moreover, the fruit oil from both populations are characterized by their richness in unsaturated fatty acids, particularly monounsaturated ones. The major identified fatty acids with GC/MS analysis of fatty acid methyl esters for Bizerte and Soliman populations are oleic $(20.20 \pm 1.42$ and $23.9 \pm 2.87 \%$, respectively), erucic $(20.82 \pm 1.60$ and $22.04 \pm 2.65 \%$, respectively) and linoleic (24.09 \pm 2.47 and $21.34 \pm 2.76 \%$, respectively) acids. Besides, analysis of tocopherols allowed the identification of two isoforms ( $\alpha$ - and $\gamma$-tocopherols). The $\alpha$-tocopherol was found as the prominent one in the two fruit oils and was most important in Soliman population than in Bizerte one $(31.13 \pm 2.45 \mathrm{mg} / \mathrm{kg}$ against $28.88 \pm$ $2.21 \mathrm{mg} / \mathrm{kg})$.

\section{INTRODUCTION}

The Brassicaceae Burnett family, also called Cruciferae or mustard family, includes 25 tribes, about 338 genera and some 3,709 species (AlShehbaz et al., 2006). Cakile Mill. genus belongs to the Brassiceae DC. tribe (Gabr, 2018). The species number of this genus is undefined and varied from 6 to 15 ones (Warwick and Sauder,
2005). In Tunisia, according to Le Floc'h et al. (2010) and to Dobignard and Chatelain (2011), this genus is represented by one species Cakile maritima subsp. maritima Scop. synonym of $C$. aegyptiaca Willd., C. latifolia Poir., C. edentulata Jord., C. littoralis Jord. and C. maritima subsp. maritima Willd.) Nyman. It is a glabrous, 
succulent annual herb. The segmented fruit is a siliqua consisting of 2 monospermous parts (Pottier-Alapetite, 1979; Cordazo, 2006; Davy et al., 2006; Merchaoui et al., 2016). It is known as sea rocket growing along sandy coasts and so reported as an obligate halophyte tolerant to salt spray (Munns and Termaat, 1986). In Tunisia, C. maritima subsp. maritima is typical of coastal dune vegetation, abundant around sandy beaches from North to South (PottierAlapetite, 1979). In addition to its ecological role in coastal dune and saline soil stabilization (Davy et al., 2006), C. maritima subsp. maritima was reported having medicinal and therapeutic properties (Ksouri et al., 2012; Merchaoui et al., 2016). All parts of the plant have a high antioxidant capacity (Merchaoui et al., 2016; Omer et al., 2019). Previous studies reported its antibacterial, antifungal, and molluscicidal activities (Casal and Casal, 2004; Sellam et al., 2007; Meot-Duros et al., 2008; Radwan et al., 2008; Cerniauskaite, 2010; Ksouri et al., 2012; Omer et al., 2016) and its nutritive values (Hedrick, 1972; Cornucopia, 1990; Guil-Guerrero et al., 1999). Several research works were carried out concerning this species; in particular the effects of salinity on germination, growth and seed production (Debez et al., 2004; Megdiche et al., 2007; Ghars et al., 2009; Debez et al., 2018), its ecophysiology (Ellouzi et al., 2011; Debez et al., 2012, 2013; Ben Hamed et al., 2014, 2016; Belghith et al., 2018; Arbelet-Bonnin et al., 2018, 2019), its antioxidant activity (Ben Amor et al., 2006, 2007; Ksouri et al., 2007; Meot-Duros et al., 2008; Ellouzi et al., 2011; Ben Mansour et al., 2018; Fuochi et al., 2019), polyphenol (Ksouri et al., 2007; Ben Mansour et al., 2018) and

\section{METHODOLOGY}

3.1 Plant material: Fresh fruits of $C$. maritima were collected at maturity in July 2018 from two salty Tunisian coastal sites; Soliman (North East of Tunisia, semi-arid bioclimatic stage, $36^{\circ} 42^{\prime} \mathrm{N}, 10^{\circ} 29^{\prime} \mathrm{E}$ ) and Bizerte (Extreme North of Tunisia, sub-humid bioclimatic stage, $\left.37^{\circ} 16^{\prime} \mathrm{N}, 9^{\circ} 52^{\prime} \mathrm{E}\right)$. Voucher specimens (Cmm 1 - flavonoid constituents (Shams et al., 2010). Other works have been focused on the allelopathic effects of its extracts (El-Amier and Abdullah, 2014). Besides, Clausing et al. (2000) and Kadereit et al. (2005) have studied its historical biogeography and phylogeography. Gandour et al. (2008) highlighted the genetic diversity of this species around Tunisian coasts. Zarrouk et al. (2003), Ghars et al. (2006) and Gandour et al. (2011) determined the composition of the lipid fraction isolated from the Tunisian C. maritima seed oil and mentioned it as a potential source of seed oil for industrial use. To the best of our knowledge no work has previously be done on $C$. maritima mature fruit oil except this of Gandour et al. (2011) where authors worked on immature fruits from plants cultivated in greenhouse and not on natural and spontaneous populations. Therefore, the present research was conducted, in the objective to determine fatty acid and tocopherol contents of the oil extracted from fruits collected on two wild populations of the Tunisian C. maritima growing in two localities in Tunisia (Soliman and Bizerte). In addition, this present research work gives anatomical characteristics of the $C$. maritima fruit knowing that previous histological studies of this species have only concerned the leaf anatomy of $C$. maritima Scop. subsp. maritima (Ciccarelli et al., 2010), the stem and the leaf anatomy of $C$. maritima Scop. subsp. aegyptiaca (Willd.) (Gabr, 2017) and the root, stem and leaf anatomy of $C$. maritima Scop. subsp. euxina (Pobed.) Nyár. (Jianu et al., 2014). Our results would add valuable information to the existing knowledge on the phytochemistry and the anatomical features of fruit.

5) identified by the botanist Prof. Fethia Harzallah-Skhiri were deposited in the herbarium of the Laboratory of Bioresources: Integrative Biology and Valorization (LR14ES06), High Institute of Biotechnology of Monastir, Tunisia. The harvested material was shade-dried then grounded into a 
homogenous fine grade powder using an electric grinder (Duronic CG 250 Premium 250 W). Powder samples were stored at $2{ }^{\circ} \mathrm{C}$ until further analyses. Also, some siliquas collected on Soliman population are kept aside for fruit anatomical studies.

\subsection{Anatomical studies: Anatomical} investigations were carried out on transversal sections (20-30 $\mu \mathrm{m}$ in thickness) of fresh fruits prepared previously using a razor blade for a free hand cutting, according to the usual techniques (Cutler et al., 2008). All the sections were bleached in sodium hypochlorite solution $(15 \%)$ for $10-15$ min, washed three times in water and successively rapidly in water/acetic acid 5\% (v/v) and stained in alun carminegreen iodine combination for $15 \mathrm{~min}$. The best sections were washed in distilled water and mounted on glass slides using glycerine gel. Sections were examined under a light VWR Microscope and representative fields were selected and photographed with the camera attached to the microscope at a magnification of $\times 100$ and $\times$ 400. For the description purpose, we used some help books (Esau, 1977; Fahn, 1979, 1990).

3.3 Cakile maritima fruit oil extraction: Fifty g of each sample fruit powder (dried fruits containing seeds) were placed into a cellulose paper cone and extracted using hexane in a Soxhlet apparatus for $8 \mathrm{~h}(18-22$ cycles $/ \mathrm{h})$. Extractions were performed at least three times. The hexane was removed with a rotary vacuum evaporator in a water bath at $40^{\circ} \mathrm{C}$. The total oil recovered was weighed and stored at $-20^{\circ} \mathrm{C}$ until analysed. The oil yield obtained from 100 $\mathrm{g}$ of fruit powder was determined to calculate the lipid content. The result is expressed as the lipid percentage in the mature fruits containing seeds powder.

\subsection{Fatty acid Methyl Esters (Fames)} analysis: Fatty acid methyl-esters (FAMEs) of the total lipids were prepared according to the IUPAC 2.301 IUPAC 2.301 (1992) standard procedure. The lipid extract was esterified to form FAMEs, which are quantified by gas chromatography-mass spectrometry (GC/MS). Thus, $200 \mu \mathrm{L}$ aliquot of the oil was dissolved in
$2 \mathrm{~mL}$ of hexane and introduced into a test tube. Then, $0.5 \mathrm{~mL}$ of sodium methylate $\left(\mathrm{CH}_{3} \mathrm{ONa}\right.$, $3 \%$ in methanol) was added. The resulting mixture was stirred and $0.2 \mathrm{~mL}$ of $1 \mathrm{~N} \mathrm{H}_{2} \mathrm{SO}_{4}$ and $1.5 \mathrm{~mL}$ of sodium chloride were added. The reaction mixture was agitated for $1 \mathrm{~min}$. After decantation, $1 \mu \mathrm{L}$ of the recovered hexane phase containing FAMEs was analysed in splitless mode.

3.5 Chromatographic analysis: The gas chromatography mass spectrometry (GC/MS) analyses were performed on a gas chromatograph HP $6890 \mathrm{~N}$ interfaced with an HP 5975B mass spectrometer (Agilent Technologies, Palo Alto, California, USA) with electron impact ionization $(70 \mathrm{eV})$. A TraceFAME capillary column $(100 \mathrm{~m} \times 0.25 \mathrm{~mm} \times$ $0.25 \mu \mathrm{m}$ film thickness; Thermo Scientific, Waltham, MA, USA) was used for the FAMEs separation. The oven temperature was programmed to $100^{\circ} \mathrm{C}$ for $5 \mathrm{~min}$, raised to $240^{\circ} \mathrm{C}$ at a rate of $5^{\circ} \mathrm{C} / \mathrm{min}$ and held isothermal for $15 \mathrm{~min}$. The carrier gas was helium with a flow rate of $1.2 \mathrm{ml} / \mathrm{min}$. Scan time and mass range were $1 \mathrm{~s}$ and $45-500 \mathrm{~m} / \mathrm{z}$, respectively. Identification of FAMEs was made by using the NIST and Wiley GC/MS library and by comparing their retention times with those of 37 authentic standards purchased from SigmaAldrich (Steinheim, Germany). The percent of FAMEs were calculated with reference to the total fatty acids.

3.6 Tocopherol analysis: Tocopherols composition was determined by High Performance Liquid Chromatography (HPLC) according to the standard method ISO 9936 (2012). Sample solutions were prepared by dissolving $4 \mathrm{~g}$ of oil in $25 \mathrm{~mL}$ of $n$-heptane and filtered through $0.45 \mu \mathrm{m}$ PTFE filter (Polytetrafluoroethylene) prior to injection. The HPLC system was equipped with an HP Agilent 1200 pump (Palo Alto, CA), coupled with an Agilent 1100 Series fluorescence detector set at the wavelengths $\lambda=295$ and 330 $\mathrm{nm}$ for excitation and emission, respectively. A $20 \mu \mathrm{L}$ of each sample solution and calibrated standard solutions (containing $a-, \beta-, \gamma-, \delta$ tocopherols with varied concentrations (3-6 
$\mu \mathrm{g} / \mathrm{mL}$ ) were injected. The column was a normal phase YMC-Pack SIL column $(250 \times 2$ mm ID, $5 \mu \mathrm{m}$; YMC Co., Kyoto, Japan). Eluent used was a $3.85 \%$ (volume fraction) of $\mathrm{THF}$ solution in $n$-heptane at a flow rate of $1 \mathrm{ml} / \mathrm{min}$.

3.7 Statistical analysis: The analyses are made in triplicate and the results are expressed as mean value \pm standard deviation. The data

\section{RESULTS AND DISCUSSION}

\subsection{Anatomical features of Cakile} maritima: Cakile maritima fruit is an indehiscent heteroarthrocarpic siliqua in an oblong shape with a joint that divides the fruit laterally into two superposed asymmetric segments supporting 2 lateral horns. The joint region has been defined as the articulating surface between the two fruit segments which may abscise at maturity containing the seed (Al-Shehbaz, 1985). The proximal and the distal segments of the indehiscent siliqua are monospermous (each one contains only one viable seed) and sizes of the distal segment and of its corresponding seed are more important than those of the proximal one. Transverse section through the siliqua of $C$. maritima shows the two valves of the ovary which margins are retained in the replum, and separated by the occurrence of the seed in the center (Fig. 1a). Ovary pericarp surrounding developing seed is differentiated into three major tissue types: an external exocarp, a central mesocarp and an internal endocarp. The exocarp is constituted of a one layer of arranged rectangular, or circular cells. Most of them are large and isodiametric. A thin cuticle covers the surface of this tissue (Figs. $1 \mathrm{~b}, \mathrm{c})$. The mesocarp is composed of $8-12$ layers of thin-walled parenchymous cells. The four first layers constitute the chlorenchyma were analysed using analysis of variance (ANOVA). The significance of the differences between means were determined at $p$ values < 0.05 using Duncan's multiple range test and by calculating Standard Error (SE) of various treatments. All analyses were performed using SPSS version 18.0 for windows.

with isodiametric large cells. The successive parenchyma tissue was formed by large radially elongated thin wall cells, in which are diffused the vascular bundles (Fig. 1d). The innermost layer was rather constituted by large tangential cells. The first large parenchyma cells were characterized by the presence of large amounts of starch grains and solitary oil drops (Fig. 1e). A conspicuous observation was made at the occurrence of large idioblasts constituted by prismatic crystals (Figs. 1c, f) refracting and shinning in the subepidermic cells of this halophyte plant. Those appeared as dense globular form, and the constituent units are like glass flakes. They generally form within cells, in our study, they may be extracellular. He et al. (2014) reported the occurrence of a large categories of biominerals in plants such as calcium oxalate crystals, calcium carbonate, and silica. Those authors mentioned that functions of biominerals may depend on their shape, size, quantity, and localization. Calcium oxalate is the most abundantly biomineral present in higher plants, found in a variety of defined shapes such as raphide, druse, styloid, prismatic and sand crystals (Nakata, 2003, 2012). Their occurrence in C. maritima has not been reported earlier. 

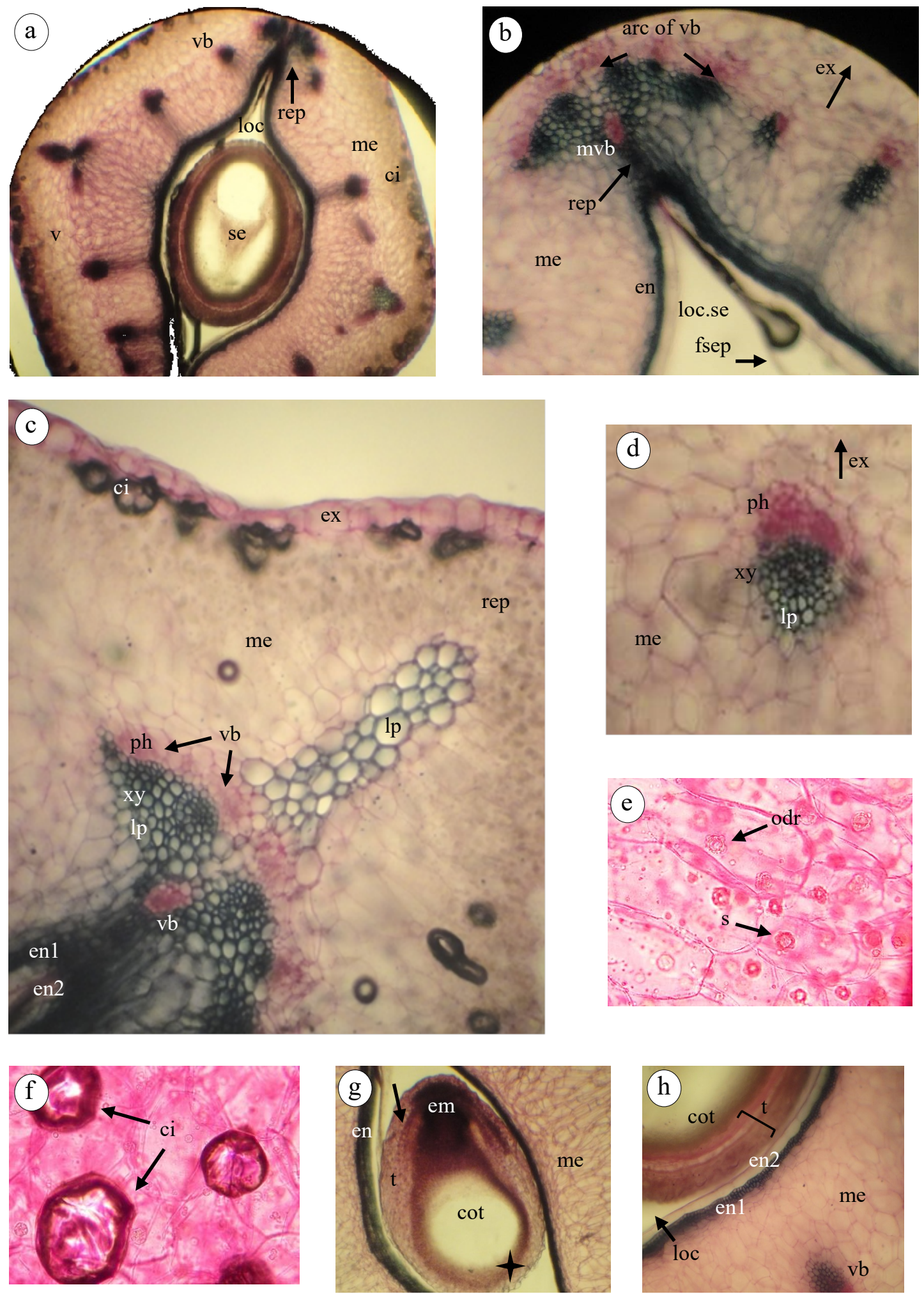

Fig. 1. Cross sections of Cakile maritima immature fresh fruit. (a) Cross section of the fruit derived from siliqua valves and the one immature seed in the loculus. Two fused carpels with replum formed from persistent placenta and connected by false septum (valves are equivalent to the mature ovary walls) $(\times 100),(\mathbf{b}, \mathbf{c})$ Valve tissues under increased magnification, showing endocarp1, endocarp2 and mesocarp. The last tissue contains the vascular bundles. The replum or the region of valve joint, showing parenchyma lignified wall cells, vascular bundles in arch disposition, located in inner 
region of the joint zone. The exocarp and the subepidermic cells containing crystal idioblasts $(\times 400)$, $(\mathbf{d})$ Detail of the vascular bundle $(\times 400)$, (e) Magnified view of chlorenchyma cells showing oil drops and some starch grains $(\times 600),(\mathbf{f})$ Magnified view of the crystal idioblasts shinning and berefringent $(\times 600)(\mathbf{g})$ The unique seed in one loculus limited by the endocarp2. The seed is protected by layers forming the testa. Oil drops and starch grains are identified in testa and cotyledon $f(\times 100)$, (h) Detail of the testa, endocarp and disposition of vascular bundles $(\times 400)$.

arc of vb. - vascular bundle of the joint region, ci. - crystals idioblasts, cot. - cotyledon, em. - embryo, en. - endocarp, en1. - endocarp1, en2. - endocarp2, ex. - exocarp, fsep - false septum, lp. - lignified parenchyma, loc. - loculus, me. mesocarp, mvb. - middle vascular bundle, odr. - oil drops, ph. - phloem, rep. - replum, se. - seed, s. - starch, t. - testa, - v. - valve, vb. - vascular bundle, xy. - xylem

The sole work of Ciccarelli et al. (2010) reported the observation of idioblasts in leaves of Cakile maritima subsp. maritima Scop., but their shapes and size are different from our find. Anitha and Sandhiya (2014) and Leme and Scremin-Dias (2014) identified also in leaves from studied plants structure crystals which looks like those observed in our fruit samples. Coté (2009) studied the diversity and distribution of idioblasts producing calcium oxalate crystals in Dieffenbachia seguine and observed scattered among pollen, prismatic crystals which are also difficult to see strongly birefringent under crossed polarizers. Contrariwise, the same structures are reported in Euonymus sp., Celastraceae shrub (Schweingruber et al., 2012) and in parenchyma cells for Mangifera indica L. wood samples (Gupta et al., 2017). Those authors think that their occurrence can be accounted to the adaptation of the plant to the local microclimatic conditions or side effect due to mining stress. Abd Elhalim et al. (2016) noted an increase in the number of calcium oxalate crystals in Zygophyllum album L. organs and reported that this feature is related to xerophytic adaptation and that calcium ions increase plant salt tolerance. Plants induce calcium oxalate crystal formation in the aim to remove excess of biologically active calcium when other mechanism has become saturated (Borchert, 1985, 1986; Franceschi and Horner, 1980; Pennisi and McConnell, 2001; Volk et al., 2002; Faheed et al., 2013). A characteristic anatomy was distinguished for the tissues at the valves junction (replum). In fact, this region in constituted by a cluster of wall lignified cells directed to the exocarp. On the opposite side, 5-6 vascular bundles were observed arranged in the form of an arch, constituted by phloem superposed by xylem (Figs. 1b, c). The last tissue was surrounded by lignified wall parenchyma cells. A single bundle is observed towards the inside near the loculus. Bundles are collateral and in primary type. The endocarp is a thin tissue composed of 2-3 layers of small lignified cells (end1) and one layer of tangential elongated and thin cells surrounding the seed (end2) (Figs. 1g,h). The seed coat typically consists of 8-9 layers constituted by cellulosic walled cells including the outer and inner testa (Figs. 1g, h). The first 3 layers are broad thinwalled, the outermost one is distinguished by its isodiametric large cells recovered with a sinuous wall. The following 5 layers are less wide and tangentially elongated. The innermost layer is larger.

4.2 Fruit oil content and fatty acid composition: Expressed on the dry weight basis, fruit oil content was $9.89 \pm 0.06 \%$ for $C$. maritima population from Soliman and $8.41 \pm$ $0.04 \%$ for those from Bizerte. The fruit oil contents from the both Tunisian coastal sites are slightly different. GC analysis of FAMEs from the two fruit oils revealed the presence of eleven saturated, monounsaturated and polyunsaturated fatty acids with some differences according to the locality of harvest (Table 1). The fruit oils from both Bizerte and Soliman populations, are characterized by their richness in unsaturated fatty acids (UFA) (82.16 and $77.9 \%$, respectively), particularly monounsaturated ones (MUFA) (45.57 \pm 4.06 and $49.74 \pm 5.21 \%$, respectively). C. maritima fruit oils were characterized by an unsaturated/saturated (U/S) ratio of $4.61 \pm$ 0.51 and $3.53 \pm 0.34$, respectively. A high ratio of $\mathrm{U} / \mathrm{S}$ is regarded favourable for the reduction of serum cholesterol and atherosclerosis and 
prevention of heart diseases (Oomah et al., 2002). The most relative abundant saturated fatty acid (SAFA) detected in fruit oil from the two populations of $C$. maritima is palmitic acid $(11.57 \pm 1.34$ and $16.38 \pm 2.05 \%$, respectively). The other three SAFA are at less important percentages varying from $0.19 \pm 0.02$ to $3.61 \pm$ $0.35 \%$ and from $0.14 \pm 0.02$ to $4.72 \pm 0.61 \%$, respectively. The two oils are rich in unsatured fatty acids represented particularly by oleic (C18:1 n-9), erucic (C22:1, cis-13), and linoleic $(\mathrm{C} 18: 2 \mathrm{n}-6)$ acids varying from $20.20 \pm 1.42$ to $24.09 \pm 2.47 \%$. Oleic acid is $20.20 \pm 1.42$ and $23.9 \pm 2.87 \%$, respectively, while linoleic acid is $24.09 \pm 2.47$ and $21.34 \pm 2.76 \%$, respectively. The erucic acid is also abundant (20.82 \pm 1.60 and $22.04 \pm 2.65 \%$, respectively). Fruit oil from Soliman is richer in palmitic, stearic, oleic, 11 eicosenoic and erucic acids. Fruit oil from Bizerte is particularly characterised by palmitoleic, linoleic, arachidic, and $\alpha$-linolenic acids. Comparing our results with the sole work done one fruits (Gandour et al. 2011), but immature ones, we reported differences in the percent of the majority of the fruit oil fatty acids, particularly palmitic, oleic, 11-Eicosenoic, $a$-Linolenic and erucic acids. Linoleic and $a$ linolenic acids prevent deficiency symptoms and cannot be synthesized by humans (Paola Benatti et al., 2004). According to Russo (2009), they have an important cardioprotective effect in the secondary prevention of sudden cardiac death due to arrhythmias. While, oleic acid has been described as a regulator of immune function and health (Miles and Calder, 1998). Sales-Campos et al. (2013) demonstrated that oleic acid, which is naturally found in olive oil and is a major component of the Mediterranean diet, presents different properties that can be useful both in the immunomodulation, treatment and prevention of different types of disorders such as cardiovascular or autoimmune diseases, metabolic disturbances, skin injury and cancer. However, fruit oil of C. maritima from Bizerte and Soliman contains high proportions of erucic acid (20.82 and 22.04\%, respectively), a compound naturally produced in green plants, and especially in members from the Brassicaceae (Sahasrabudhe, 1977; Economic Research Service USDA Crambe, 1996; Anneken, 2006). It is considered as antinutritional for both humans and animals (Rajcan et al., 1999), but widely used in the industry (Domergue et al., 1999; Kaushik and Agnihotri, 2000). According to Karleskind (1996), Zarrouk et al. (2003) and Ghars et al. (2006), seeds of C. maritima produce an oil which contains a high level of erucic acid exceeding $25 \%$. 
Table 1: Fatty acid profile (as \% of total fatty acids) of fruit oil from two Tunisian populations of Cakile maritima (Bizerte and Soliman).

\begin{tabular}{lrrr}
\hline \multirow{2}{*}{ Fatty acid } & \multirow{2}{*}{ RT (min) } & \multicolumn{2}{c}{ Fatty acid area (\%) } \\
\cline { 3 - 4 } Saturated & & \multicolumn{1}{c}{ Soliman } \\
\hline Palmitic acid (C16:0) & 24.42 & $11.57 \pm 1.34^{\mathrm{a}}$ & $16.38 \pm 2.05^{\mathrm{b}}$ \\
Stearic acid (C18:0) & 28.06 & $2.42 \pm 0.20^{\mathrm{a}}$ & $4.72 \pm 0.61^{\mathrm{b}}$ \\
Arachidic acid (C20:0) & 30.23 & $3.61 \pm 0.35^{\mathrm{a}}$ & $0.81 \pm 0.11^{\mathrm{b}}$ \\
Behenic acid (C22:0) & 34.9 & $0.19 \pm 0.02^{\mathrm{a}}$ & $0.14 \pm 0.02^{\mathrm{a}}$ \\
\hline Monounsaturated & & \\
\hline Palmitoleic acid (C16:1 n-7) & 25.17 & $2.37 \pm 0.19^{\mathrm{a}}$ & $0.23 \pm 0.03^{\mathrm{b}}$ \\
cis-Vaccenic acid (C18:1 n-7) & 29.23 & $0.95 \pm 0.08^{\mathrm{a}}$ & $0.64 \pm 0.07^{\mathrm{a}}$ \\
Oleic acid (C18:1 n-9) & 28.77 & $20.20 \pm 1.42^{\mathrm{a}}$ & $23.9 \pm 2.87^{\mathrm{a}}$ \\
11-Eicosenoic acid (C20:1 n-9) & $1.23 \pm 0.04^{\mathrm{a}}$ & $2.93 \pm 0.26^{\mathrm{b}}$ \\
Erucic acid (C22:1, cis-13) & 31.95 & & \\
\hline Polyunsaturated & 35.14 & $20.82 \pm 1.60^{\mathrm{a}}$ & $22.04 \pm 2.65^{\mathrm{a}}$ \\
\hline Linoleic acid (C18:2 n-6) & & & \\
$a$-Linolenic acid (C18:3 n-3) & 29.68 & $24.09 \pm 2.47^{\mathrm{a}}$ & $21.34 \pm 2.76^{\mathrm{a}}$ \\
\hline SAFA & 30.95 & $12.5 \pm 1.28^{\mathrm{a}}$ & $6.82 \pm 0.75^{\mathrm{b}}$ \\
MUFA & & $17.79 \pm 0.97^{\mathrm{a}}$ & $22.05 \pm 2.07^{\mathrm{b}}$ \\
PUFA & & $45.57 \pm 4.06^{\mathrm{a}}$ & $49.74 \pm 5.21^{\mathrm{b}}$ \\
U/S & & $36.59 \pm 2.65^{\mathrm{a}}$ & $28.16 \pm 2.42^{\mathrm{b}}$ \\
\hline
\end{tabular}

Means \pm SD with the same letter (s) in the same line are not significantly different $(\mathrm{p}>0.05)$

* Retention time on TRACE TR-225 GC Column, SAFA - saturated fatty acids, MUFA - monounsaturated fatty acids, PUFA - polyunsaturated fatty acids, U/S - unsaturated/saturated ratio.

Content in oil for fruit was less important that this reported for seeds by Zarrouk et al. (2003), Ghars et al. (2006) and Gandour et al. (2011). In fact, the fruit contains a low number of seeds. In our study we have counted a mean number of 2 per siliqua. The amount of oil found corresponds to the seeds and the fruit tissues that were not reported elsewhere. The occurrence of oil drops in mesocarp parenchyma cells and in seed teguments support our results. Then, based on these results, we considered that the $C$. maritima fruit oil can be used for nonedible purposes, and it might compete successfully with other plant oils as a source of fatty acids essentially for industrial applications.
4.3 Tocopherol content: Fruit oil content in tocopherol for the two C. maritima populations is presented in Table 2. Two isoforms, $a$-tocopherol and $\gamma$-tocopherol are detected and identified in all samples. $\delta$ tocopherol and $\beta$-tocopherol are never found. Individual tocopherol contents exhibited some variations among the two populations. The $\alpha$ tocopherol is the main one in the two fruit oils, moreover its content in Soliman population is higher than in Bizerte one $(31.13 \pm 2.45 \mathrm{mg} / \mathrm{kg}$ against $28.88 \pm 2.21 \mathrm{mg} / \mathrm{kg}$ ). Whereas, $\boldsymbol{\gamma}$ tocopherol is better represented in fruit oil from Bizerte $(4.48 \pm 0.49 \mathrm{mg} / \mathrm{kg})$ then in this from Soliman (3.27 $\pm 0.36 \mathrm{mg} / \mathrm{kg})$ plant population. 
Table 2. Tocopherol content $(\mathrm{mg} / \mathrm{kg}$ ) of fruit oil from two Tunisian populations of Cakile maritima (Bizerte and Soliman).

\begin{tabular}{|c|c|c|}
\hline \multirow{2}{*}{ Identified Tocopherols } & Bizerte & Soliman \\
\hline & \multicolumn{2}{|c|}{ Concentration $(\mathrm{mg} / \mathrm{kg})$} \\
\hline$a$-Tocopherol & $28.88 \pm 2.21^{\mathrm{a}}$ & $31.13 \pm 2.45 \mathrm{a}$ \\
\hline$\gamma$-Tocopherol & $4.48 \pm 0.49^{\mathrm{a}}$ & $3.27 \pm 0.36 \mathrm{a}$ \\
\hline Total tocopherols $(\mathrm{mg} / \mathrm{kg})$ & $33.37 \pm 2.78 \mathrm{a}$ & $34.42 \pm 2.82 \mathrm{a}$ \\
\hline
\end{tabular}

Means \pm SD with the same letter $(s)$ in the same line are not significantly different $(p>0.05)$

To treat with oxidative stress, plants have developed among others, two protective mechanisms, enzymatic and non-enzymatic detoxification. The latter involves vitamin $\mathrm{E}$, namely tocopherols ( $\alpha$-tocopherol, $\beta$ tocopherol, $\gamma$-tocopherol and $\delta$-tocopherol) and tocotrienols known by their antioxidant power (Alscher and Heath, 2002). In response to abiotic stress, plants accumulate $\alpha$-tocopherol and $\gamma$-tocopherol in leaves (Munné-Bosch, 2005). According to Horvath et al. (2006), $\alpha$ tocopherol is the predominant tocopherol form in photosynthetic tissues, while $\gamma$ - and $\delta$ tocopherols are predominant in seeds, fruits, and storage organs of Dicots. Vitamin $\mathrm{E}$ is an essential micronutrient found mainly in vegetable oils and in products derived from those oils (Wenneras et al., 2013). Published data related to the tocopherol contents in the fruit oil of C. maritima are not available. Although, in Tunisia, the studies of Ellouzi et al. (2011, 2013) showed the positive role of tocopherols in stress tolerance. $C$. maritima can rapidly evolve physiological and antioxidant mechanisms to adapt to salt and manage the oxidative stress. They also specify that C. maritima has a large pool of $\alpha$ tocopherols. In contrary, the pool of $\gamma$ tocopherols is less important. $\gamma$-tocopherols seem to respond to osmotic stress but not to

\section{REFERENCES}

Abd Elhalim ME, Abo-Alatta $\mathrm{O}$ Kh, Habib SA. and Abd Elbar OH: 2016. The anatomical features of the desert halophytes Zygophyllum album L.F. and Nitraria retusa (Forssk.). Annales of Agricultural Sciences 61(1): 97-104. salt induced oxidative stress unlike the $\alpha$ tocopherols. Besides, Goffman and Mollers (2000) revealed that the tocopherol content of Brassica napus L. oil seed consists of $64 \% \gamma$ tocopherol, 35\% $\alpha$-tocopherol, and less content in $\delta$-tocopherol. Likewise, $\alpha$ - and $\gamma$-tocopherols were the major isomers determined by Scialabba et al. (2010) in dry seeds of nine Brassica species, $\delta$-tocopherol was present in traces and $\beta$-tocopherol was absent. Then, this study reported for the first time the anatomical features of $C$. maritima fruit with the occurrence of large crystal idioblasts, oil drops and some starch grains in the first layers of the mesocarp. Those biominerals should be calcium oxalate crystals produced by $C$. maritima to remove excess oxalate or calcium and so increase its salt tolerance. Furthermore the composition of $C$. maritima fruit oil is characterized by relatively high unsaturated fatty acids particularly oleic, erucic and linoleic acids. The cultivation of this plant can have significant industrial applications and become profitable economically. Indeed, the higher content of $C$. maritima fruit oil in tocopherols; specially $\alpha$-tocopherol, permit to speculate that this species might be considered as a potential source of natural antioxidant. The oil must be extracted directly from the fruit without the procedure of extracting the seeds.

Alscher RGEN. and Heath LS: 2002. Role of superoxide dismutases (SODs) in controlling oxidative stress in plants. Journal of Experimental Botany 53: 1331 1341. 
Al-Shehbaz IA: 1985. The genera of Brassiceae (Cruciferae; Brassicaceae) in the southeastern United States. Journal of the Arnold Arboretum of Harvard University 66: 279-351.

Al-Shehbaz IA, Beilstein MA. and Kellog EA: 2006. Systematics and phylogeny of the Brassicacea (Cruciferae): an overview. Plant Systematics and Evolution 259: 89120.

Anitha A R. and Sandhiya T: 2014. Occurrence of calcium oxalate crystals in the leaves of medicinal plants. International Journal of Pharmacognosy 1(6): 389-393.

Anneken DJ, Both S, Christoph R, Fieg G, Steinberner U. and Westfechtel A: 2006. Fatty Acids. In: Ullmann's Encyclopedia of Industrial Chemistry, online edition. Wiley-VCH, Weinheim.

Arbelet-Bonnin D, Ben-Hamed-Louati I, Laurenti P, Abdelly C, Ben Hamed K. and Bouteau F: 2018. Cellular mechanisms to survive salt in the obligate halophyte Cakile maritima. Plant Science 272: 173-178.

Arbelet-Bonnin D, Ben-Hamed-Louati I, Laurenti P, Abdelly C, Ben Hamed K. and Bouteau F: 2019. Cakile maritima, a promising model for halophyte studies and a putative cash crop for saline agriculture. Advances in Agronomy 55: 4578.

Belghith I, Senkler J, Hildebrandt T, Abdelly C, Braun HP. and Debez A: 2018. Comparative analysis of salt-induced changes in the root proteome of two accessions of the halophyte Cakile maritima. Plant Physiology and Biochemistry 130: 20-29.

Ben Amor N, Jimenez A, Megdiche W, Lundqvist M, Sevilla F. and Abdelly C: 2006. Response of antioxidant systems to $\mathrm{NaCl}$ stress in the halophyte Cakile maritima. Physiol. Plantarum 126: 446457.

Ben Amor N, Jimenez A, Megdiche W, Lundqvist M, Sevilla F. and Abdelly C: 2007. Kinetics of the anti-oxidant response to salinity in the halophyte Cakile maritima. J. Integr. Plant Biology 49(7): 982-992.

Ben Hamed I, Biligui B, Arbelet-Bonnin D, Abdelly C, Ben Hamed K. and Bouteau F: 2014. Establishment of a cell suspension culture of the halophyte Cakile maritima. Advances in Horticultural Science 28(1): 43-48.

Ben Hamed K, Ben Hamad I, Bouteau F. and Abdelly C: 2016. Insights into the ecology and the salt tolerance of the halophyte Cakile maritima using multidisciplinary approaches. In: Khan MA, Ozturk M, Gul B, Ahmed MZ (Editor), Halophytes for Food Security in Dry Lands. Publication Elsevier, Oxford, pp. 197-211.

Ben Mansour R, Dakhlaouia S, Msahli W, Ksouri R. and Megdiche-Ksouri W: 2018. Differential responses of Cakile maritima at two development stages to salinity: changes on phenolic metabolites and related enzymes and antioxidant activity. Journal of Medicinal Chemistry 8(4): 100-108.

Borchert R: 1985. Calcium-induced patterns of calcium-oxalate crystals in isolated leaflets of Gleditsia triacanthos L. and Albizia julibrissin Durazz. Planta 165(3): 301-310.

Borchert R: 1986. Calcium acetate induces calcium uptake and formation of calcium-oxalate crystals in isolated leaflets of Gleditsia triacanthos L. Planta 168(4): 571-578.

Casal MT. and Casal M: 2004. Maimonides and the chemotherapy of infectious diseases. Revista Espanola de Quimioterapia 17(3): 289-294.

Cerniauskaite D: 2010. Glucosinolates Myrosinase: Synthèse de Substrats Naturels et Artificiels, Inhibiteurs et Produits de Transformation Enzymatique. Université d'Orléans, France.

Ciccarelli D, Balestri M, Pagni AM. and Forino LMC: $\quad 2010 . \quad$ Morpho-functional 
adaptations in Cakile maritima Scop. subsp. maritima: comparation of two different morphological types. Caryologia 63(4): 411-421.

Clausing G, Vickers K. and Kadereit JW: 2000. Historical biogeography in linear system: genetic variation of sea rocket (Cakile maritima) and sea holly (Eryngium maritimum) along European coasts. Molecular Ecology 9: 1823-1833.

Cordazzo CV: 2006. Seed characteristics and dispersal of dimorphic fruit segments of Cakile maritima Scopoli (Brassicaceae) population of southern Brazilian coastal dunes. Brazilian Journal of Botany 29(2): 259-265.

Cornucopia S: 1990. A Source Book of Edible Plants. Kampong Publications.

Coté GG: 2009. Diversity and distribution of idioblastes producing calcium oxalate crystals in Dieffenbachia seguine (Araceae). American Journal of Botany 96(7): 1245 1254.

Cutler DF, Botha CEJ. and Stevenson DW: 2008. Plant Anatomy: an Applied Approach. Oxford, Blackwell, Malden, USA, 312 pp.

Davy AJ, Scott R. and Cordazzo CV: 2006. Biological flora of the British Isles: Cakile maritima Scop. Journal of Ecology 94: 695-711.

Debez A, Ben Hamed K, Grignon C. and Abdelly C: 2004. Salinity effects on germination, growth, and seed production of the halophyte Cakile maritima. Plant Soil 262: 179-189.

Debez A, Braun HP, Pich A, Taamalli W, Koyro HW, Abdelly C. and Huchzermeyer B: 2012. Proteomic and physiological responses of the halophyte Cakile maritima to moderate salinity at the germinative and vegetative stages. Journal of Proteomics 75(18): 5667-5694.

Debez A, Ben Rejeb K, Ghars MA, Gandour M, Megdiche W, Ben Hamed K, Ben Amor N, Brown SC, Savoure A. and Abdelly C: 2013. Ecophysiological and genomic analysis of salt tolerance of
Cakile maritima. Environmental and Experimental Botany 92: 64-72.

Debez A, Belghith I, Pich A, Taamalli W, Abdelly C. and Braun HP: 2018. High salinity impacts germination of the halophyte Cakile maritima but primes seeds for rapid germination upon stress release. Physiologia Plantarum 164(2): 134 144.

Dobignard A. and Chatelain C: 2011. Index Synonymique de la Flore d'Afrique du Nord, Dicotyledoneae : Balsaminaceae à Euphorbiaceae, part 3. Conservatoire et Jardin Botaniques de la Ville de Genève, Geneva.

Domergue F, Chevalier S, Santarelli X, Cassagne C. and Lessire R. 1999. Evidence that oleoyl-CoA and ATPdependent elongations coexist in rapeseed (Brassica napus L.). European Journal of Biochemistry 263: 464-470.

Economic Research Service USDA Crambe: 1996. Industrial Rapeseed, and Tung Provide Valuable Oils. www.ers.usda.gov/publications/I US6/IUS6C.

El-Amier YA. and Abdullah TJ: 2014. Allelopathic effect of four wild species on germination and seedling growth of Echinocloa crus-galli (L.) P. Beauv. International Journal of Advanced Research 2(9): 287-294.

Ellouzi H, Hamed KB, Cela J, Munné-Bosch S. and Abdelly C: 2011. Early effects of salt stress on the physiological and oxidative status of Cakile maritima (halophyte) and Arabidopsis thaliana (glycophyte). Physiologia Plantarum 142(2): 128-143.

Ellouzi H, Hamed KB, Cela J, Muller M, Abdelly C. and Munne-Bosch S: 2013. Increased sensitivity to salt stress in tocopherol-deficient Arabidopsis mutants growing in a hydroponic system. Plant Signaling \& Behavior 8(2): e23136.

Esau K: 1977. Anatomy of Seed Plants. Wiley J, Sons, New York. 
Faheed F, Mazen A. and Elmohsen SA: 2013. Physiological and ultrastructural studies on calcium oxalate crystal formation in some plants. Turkish Journal of Botany 37: 139-152.

Fahn A: 1979. Secretory Tissues in Plants. Academic Press, London, New York, $302 \mathrm{pp}$.

Fahn A: 1990. Plant Anatomy. Sydney,

Butterworth-Heinemann, Oxford, 588

pp.

Fuochi V, Barbagallo I, Distefano A, Puglisi F, Palmeri R, Di Rosa M, et al:: 2019. Biological properties of Cakile maritima Scop. (Brassicaceae) extracts. European review for medical and pharmacological sciences 23: 2280-2292.

Franceschi VR. and Horner HT: 1980. Calcium oxalate crystals in plants. Botanical Review 46(4): 361-427.

Gabr DG: 2017. Various macro and micromorphological features of two species of Cakile. African Journal of Plant Science 11(12): 408-14.

Gabr DG: 2018. Significance of Fruit and Seed Coat Morphology in Taxonomy and Identification for Some Species of Brassicaceae. American Journal of Plant Sciences 9: 380_402.

Gandour M, Hessini K. and Abdelly C: 2008. Understanding the population genetic structure of coastal species (Cakile maritima): seed dispersal and the role of sea currents in determining population structure. Genetics Research 90: 167-178.

Gandour M, Tamaalli W, Trabelsi N, Hessini K, Sebei K, Debez A. and Abdelly C: 2011. How to optimize the seed and seed-oil production in the cash crop halophyte Cakile maritima? Journal of Medicinal Plants Research 5(25): 5982 5987.

Ghars MA, Debez A, Smaoui A, Zarrok M, Grignon C. and Abdelly C: 2006. Variability of Fruit and seed oil characteristics in Tunisian accessions of the halophyte Cakile maritima (Brassicaceae). In: Khan MA, Weber DJ
(Edition). Ecophysiology of High Salinity Tolerant Plants. Publication Springer, Berlin, pp. 55-67.

Ghars MA, Debez A. and Abdelly: 2009. Interaction between salinity and original habitat during germination of the annual seashore halophyte Cakile maritima. Soil Science and Plant Analysis 40: 3170_3180.

Goffman FD. and Mollers C: 2000. Changes in tocopherol and plastochromanol-8 contents in seeds and oil of oilseed rape (Brassica napus L.) during storage as influenced by temperature and air oxygen. Journal of Agricultural and Food Chemistry 48: 1605-1609.

Guil-Guerrero JL, Giménez-Martinez JJ. and Torija-Isasa ME: 1999. Nutritional composition of wild edible Crucifer species. Journal of Food Biochemistry 23(3): 283-294.

Gupta A, Gupta S. and Vishnuprasad V: 2017. Druses in the secondary xylem of Mangifera indica collected from coal Mines. Indian Journal of Pharmaceutical Sciences 29(2): 179-184.

He H, Veneklaas EJ, Kuo J. and Lambers H: 2014. Physiological and ecological significance of biomineralization in plants. Trends in Plant Science 19(3): 166 174.

Hedrick UP: 1972. Sturtevant's Edible Plants of the World. Dover Publications.

Horvath G, Wessjohann L, Bigirimana, Jansen M, Guisez Y, Caubergs R. and Horemans N: 2006. Differential distribution of tocopherols and tocotrienols in photosynthetic and nonphotosynthetic tissues. Phytochemistry 67(12): 1185-1195.

ISO 9936: 2012. Animal and Vegetable Fats and Oils - Determination of Tocopherol and Tocotrienol Contents by High-Performance Liquid Chromatography.

IUPAC (International Union of Pure and Applied Chemistry): 
1992. Standard methods for the analysis of oils, fats and derivatives. International union of pure and applied chemistry, Blackwell Scientific, Oxford.

Jianu LD, Bercu R. and Dan R: 2014. Anatomical features of the endengered plant Cakile maritima Scop. Subsp. euxina (Pobed.) Nyar. Annals of West University of Timisoara Ser Biology 17(2): 79_86.

Kadereit JW, Arafeh R, Somogyi G. and Westberg E: 2005. Terrestrial growth and marine dispersal? Comparative phylogeography of five coastal plant species at a European scale. Taxon 54(4): 861-876.

Kaushik N. and Agnihotri A: 2000. GLC analysis of Indian rapeseed-mustard to study the variability of fatty acid composition. Biochemical Society Transactions 28(6): 581-583.

Karleskind A. and Wolff JP: 1996. Oils and Fats Manual: A Comprehensive Treatise- Properties, Production, Application. TEC \& DOC Lavoisier, France, 1527 pp.

Ksouri R, Megdiche W, Debez A, Falleh H, Grignon C. and Abdelly C: 2007. Salinity effects on polyphenol content and antioxidant activities in leaves of the halophyte Cakile maritima. Plant Physiology and Biochemistry 45: 244-249.

Ksouri R, Megdiche W, Jallali I, Debez A, Magné C, Hiroko I. and Abdelly C: 2012. Medicinal halophytes: potent source of health promoting biomolecules with medical, nutraceutical and food applications. Critical Reviews in Biotechnology 32(4): 289-326.

Le Floc'h E, Boulos L. and Véla E: 2010. Catalogue Synonymique Commenté de la Flore de Tunisie. Ministère de l'Environnement et du Développement durable, Banque Nationale de Gènes, République Tunisienne, 500 pp.

Leme FM. and Scremin-Dias E: 2014. Ecological interpretations of the leaf anatomy of amphibious species of Aeschynomene L. (Leguminosae-
Papilionoideae). Brazilian Journal of Biology 74(1): 41-51.

Megdiche W, Ben Amor N, Debez A, Hessini K, Ksouri R, Zuily-Fodil Y. and Abdelly C: 2007. Salt tolerance of the annual halophyte Cakile maritima as affected by the provenance and the developmental stage. Acta Physiologiae Plantarum 29: 375 384.

Meot-Duros L, Le Floch G. and Magné C: 2008. Radical scavenging, antioxidant and antimicrobial activities of halophytic species. Journal of Ethnopharmacology 116(2): 258-262.

Merchaoui H, Hanana M. and Ksouri R : 2016. Notes ethnobotanique et phytopharmacologique sur Cakile maritima Scop. Phytotherapie 1-6.

Miles EA. and Calder PC: 1998. Modulation of immune function by dietary fatty acids. Proceedings of the Nutrition Society 57: 277 292.

Munné-Bosch S: 2005. The role of $\alpha$-tocopherol in plant stress tolerance. Journal of Plant Physiology 162: 743-748.

Munns R. and Termaat A: 1986. Whole-plant responses to salinity. Functional Plant Biology 13(1): 143-160.

Nakata PA: 2003. Advances in our understanding of calcium oxalate crystal formation and function in plants. Plant Science 164(6): 901-909.

Nakata P: 2012. Plant calcium oxalate crystal formation, function, and its impact on human health. Frontiers in Biology 7(3): 254-266.

Omer E, Elshamy A, El Gendy AN, Cai X, Sirdaarta J, White A. and Cock IE: 2016. Cakile maritima Scop. extracts inhibit the growth of some bacterial triggers of autoimmune diseases: GC-MS analysis of an inhibitory extract. Pharmacognosy Journal 8(4): 361374.

Omer E, Elshamy A, Taher R, El-Kashak W, Shalom J, White A. and Cock IE: 2019. Cakile maritima Scop. Extracts Inhibit $\mathrm{CaCo} 2$ and HeLa Human Carcinoma 
Cell Growth: GC-MS Analysis of an Anti-Proliferative Extract. Pharmacognosy Journal 11(2): 258-266.

Oomah BD, Busson M, Godfrey DV. and Drover JCG: 2002. Characteristics of hemp (Cannabis sativa L.) seed oil. Food Chemistry 76: 33-43.

Paola Benatti MC, Gianfranco Peluso MD, Raffaella Nicolai PhD. and Menotti Calvani MD: 2004. Polyunsaturated fatty acids: biochemical, nutritional and epigenetic properties. Journal of the American College of Nutrition 23(4): 281 302.

Pennisi SV. and McConnell DB: 2001. Inducible calcium sinks and preferential calcium allocation in leaf primordia of Dracaena sanderiana Hort. Sander ex M.T. Mast (Dracaenaceae). Hortscience 36: 1187-1191.

Pottier-Alapetite G: 1979. Flore de la Tunisie, Angiospermes - Dicotylédones Apétales Dialypétales, part 1. Imprimerie officielle de la république Tunisienne.

Radwan HM, Shams KhA, Tawfik WA. and Soliman AM: 2008. Investigation of the glucosinolates and lipids constituents of Cakile maritima (Scope) growing in Egypt and their biological activity. Research Journal of Medical Sciences 3(2): 182-187.

Rajcan I, Kasha KJ, Kott LS. and Beversdorf WD: 1999. Detection of molecular markers associated with linolenic and erucic acid levels in spring rapeseed (Brassica napus L.). Euphytica 105: 173 181.

Russo GL: 2009. Dietary n-6 and n-3 polyunsaturated fatty acids: from biochemistry to clinical implications in cardiovascular prevention. Biochemical Pharmacology 77(6): 937-946.

Sahasrabudhe MR: 1977. Crismer values and erucic acid contents of rapeseed oils. Journal of the American Oil Chemists' Society 54(8): 323-324.

Scialabba A, L Salvini, Faqi AS. and Bellani LM: 2010. Tocopherol, fatty acid and phytosterol content in seeds of nine wild taxa of Sicilian Brassica (Cruciferae). Plant Biosystems 144(3): 626-633.

Sellam A, Iacomi-Vasilescu B, Hudhomme P. and Simoneau P: 2007. In vitro antifungal activity of brassinin, camalexin and two isothiocyanates against the crucifer pathogens Alternaria brassicicola and Alternaria brassicae. Plant Pathology 56: 296-301.

Shams KA, Radwan HM, Tawfik WA, Habib AA. and Soliman AMM: 2010. Flavonoid constituents of Cakile maritima (Scope) growing in Egypt and their biological activity. Asian Journal of Chemistry 22(5): 3981-3988.

Warwick SI. and Sauder CA: 2005. Phylogeny of the tribe Brassiceae (Brassicaceae) based on chloroplast restriction site polymorphisms and nuclear ribosomal internal transcribed spacer and chloroplast trnL intron sequences. Canadian Journal of Botany 83: 467-483.

Wenneras C, Matsumoto K, Bochner BS, Cook-Mills JM, Asosingh K, Serpil CE, Savita PR. and Sriramarao P: 2013. Eosinophil trafficking. In: James JL, Rosenberg HF (Editor). Eosinophils in Health and Disease, Publication Elsevier Inc., pp. 121-166.

Zarrouk M, El Almi H, Ben Youssef N, Sleimi N, Smaoui A, Ben Miled D. and Abdelly C: 2003. Lipid composition of seeds of local halophytes: Cakile maritima, Zygophyllum album and Crithmum maritimum. In: Lieth $H$ (Editor). Cash Crop Halophytes: Recent Studies. Publication Kluwer Academic, pp. 121 124. 